\title{
Rhetoric and Religion: Reference to Authority in Roman Catholic Bishops' Pastoral Letters in the Ecclesiastical Province of Onitsha, Nigeria
}

\author{
Virginia C. Okafor and Adejoke O. Olugbuyi
}

\begin{abstract}
The interconnectedness of rhetoric and religion lies not only in the communicative role played by language in religion, that is, in trying to make the supernatural understandable to the humans, but also in the fact that rhetoric, as strategic use of language, is central to religion in encouraging a believer to remain in his faith or persuading a person to adopt a belief system or change of life. This article examines the use of reference to authority as a rhetorical device in selected Roman Catholic Bishops' Lenten Pastoral Letters in the Ecclesiastical Province of Onitsha, Nigeria. Aristotelian Rhetoric was adopted as the framework because of its emphasis on persuasion through three main rhetorical appeals: logos, pathos, and ethos. Data were drawn from 10 pastoral letters of five Roman Catholic bishops in five dioceses (two letters from each) out of the seven in the Ecclesiastical Province of Onitsha. The five dioceses-- Onitsha arch-diocese, Nnewi, Awka, Enugu, and Awgu dioceses-were chosen because pastoral letters are regularly published there. The 10 pastoral letters were published between 2000 and 2010 and ranged between 20 and 104 pages. They were selected, through purposive sampling, based on consistency in publication and rhetorical content. Data were subjected to discourse analysis. Analysis revealed references to six types of authorities: the holy Bible, the Vatican Council documents, the Catechism of the Catholic Church, the Canon Law, the Pope, and the Saints. The device was adopted by the bishops as a means of validating their messages of faith, love, repentance and loyalty to boost credibility.
\end{abstract}

Index Terms-Ecclesiastical province of onitsha, pastoral letters, reference to authority, rhetorical devices, roman catholic bishops.

\section{INTRODUCTION}

Rhetoric and religion are two interrelated disciplines that cannot easily be separated. Since religion is concerned with man's faith in the supernatural power, language use in religion is rhetorical as it thrives on the use of analogy and other rhetorical devices to make the supernatural understandable to the humans, to encourage loyalty to a belief system, and to win new converts to it. Emphasizing this verbal rhetoric of religion Pernot holds that the parallel between rhetoric and religion can be found in the fact that religion is intimately linked with words [1]. According to him, the spoken and written word plays an essential role in religion, as language is necessarily used to address the gods or God, to speak about the divine or the sacred, and to

Manuscript received September 30, 2015; revised November 30, 2015.

The authors are with the Federal Polytechnic, Ado-Ekiti, Ekiti State Nigeria (e-mail: chikkrisokafor@yahoo.com). express religious feeling or awareness. In his own view, Burke submits that "rhetoric is the art of persuasion, and religious cosmogonies are designed, in the last analysis, as exceptionally thoroughgoing modes of persuasion" [2].

The interconnection between rhetoric and religion justifies a rhetorical approach to the study of Roman Catholic bishops' Lenten pastoral letters in the Ecclesiastical Province of Onitsha. The pastoral letters, which promote the Roman Catholic faith, are aimed at encouraging good Christian living among the faithful, and reference to authority is a major rhetorical device deployed. It is a device that entails making an appeal to or citing an authority as a means of strengthening an argument to boost credibility. Its use in a discourse is thus aimed at increasing the speaker's trustworthiness, integrity, and reliability to enhance acceptance of message. It renders him convincing and believable as the audience takes his plans and intentions as accurate and factual [3]. An authority is usually trusted and recognized for its expertise or power, and as such is rarely challenged. This makes the device highly persuasive. Aristotelian rhetoric thus provides a unique analytical framework for this study since it centers on modes of persuasion in a discourse. According to Aristotle, persuasion in a rhetorical discourse is achieved through ethos (the speaker's character) when the speaker presents himself as knowledgeable, trustworthy, and as having the best interests of the audience at heart; through pathos (emotions) when he arouses emotions capable of modifying the judgments of the audience; and through logos (argument) when he appeals to the audience "s sense of reasoning [4]. The rhetorical approach will provide a better understanding of the Lenten pastorals as a religious discourse.

\section{Methodology and Data Presentation}

Data for the study are derived from ten Lenten pastoral letters of five Roman Catholic bishops in five out of the seven dioceses of the Ecclesiastical Province of Onitsha, that is, two pastoral letters from each diocese. The five dioceses, which include dioceses of Enugu, Nnewi, Awka, Awgu, and the Arch-diocese of Onitsha, are those where Lenten pastoral letters are published annually. The chosen pastoral letters span between 2000 and 2010 and range between 20 and 104 pages. They were purposively selected based on consistency in publication and rhetorical content. The sampled dioceses and the pastoral letters are presented in the table below: 
TABLE I: SAMPLED DIOCESES AND PASTORAL LETTERS

\begin{tabular}{|l|l|c|c|}
\hline Diocese & Pastoral Letter & $\begin{array}{l}\text { No. } \\
\text { chosen }\end{array}$ & Year \\
\hline $\begin{array}{l}\text { Arch-diocese of } \\
\text { Onitsha }\end{array}$ & $\begin{array}{l}\text { i. If Only You Have Faith (IYHF) } \\
\text { ii. The Measure of Love (TML) }\end{array}$ & 2 & 2006 \\
\hline Diocese of Enugu & $\begin{array}{l}\text { i. Okwukwe Ezi Olu (OEO) } \\
\text { ii. God is Calling us to Reconciliation } \\
\text { (GCTR) }\end{array}$ & 2 & 20010 \\
\hline Diocese of Awka & $\begin{array}{l}\text { i. Repent and Believe the Good News } \\
\text { (RBGN) } \\
\text { ii. Call to Conversion (CTC) }\end{array}$ & 2 & 2000 \\
\hline Diocese of Nnewi & $\begin{array}{l}\text { i. From Faith to Faith (FFF) } \\
\text { ii. We Walk by Faith (WWF) }\end{array}$ & 2 & 2004 \\
\hline Diocese of Awgu & $\begin{array}{l}\text { i. Living in the Amazing Love of } \\
\text { God (LALG) } \\
\text { ii. Living the Faith (LTF) }\end{array}$ & 2008 \\
\hline
\end{tabular}

\section{DATA ANALYSIS}

In the bishops ${ }^{\text {ee }}$ pastoral letters, references are made to six types of authorities: the holy Bible, the Vatican Council, the Catechism of the Catholic Church, the Canon Law, the Pope, and the Saints. These are aimed at securing audience's .compliance with the bishops' messages of faith, repentance, love and loyalty to the Roman Catholic Church.

\section{A. Reference to the Holy Bible}

The pastoral letters reveal copious references to the holy Bible as an authority to validate claims. These are in form of Biblical quotations and allusions.

\section{1) Biblical quotations}

Both direct and paraphrased quotations from the Bible are deployed. In the case of direct quotation, materials are taken verbatim from the Bible and so are enclosed in quotation marks; while in the case of paraphrased or indirect quotation, materials from the Bible are rephrased in the bishops' own words, thus enabling them to dramatize the delivery of the content of the quotation as they see fit [5]. Texts 1-4 exemplify the bishops' use of direct and indirect quotations from the Bible to validate their messages.

Text 1: Faith in Jesus Christ is a commitment that is to be nurtured so that it can grow...As faith is nurtured, the commitment progressively grows until it reaches the point where the believer lives with Christ, crucified with Him. Paul expresses this well in Galatians 2:20: "And it is no longer I who live, but it is Christ who lives in me..." [6].

This text, which relates to the theme of faith, contains a direct quotation from the holy Bible, Galatians 2:20. The quotation is enclosed in quotation marks to show that it is the exact words of Paul. Being very much concerned about the issue of faith in the province, the bishop does not just want to risk his message being ignored. So he deploys resources available to him to persuade the audience to accept his messages. He does not just stop at using metaphor to make his message effective. He finds the need to invoke the authority of the holy Bible, the book of faith of Christians which he and the faithful cherish and revere so as to ensure persuasion. The direct quotation from St. Paul's letter to the Galatians thus increases the persuasive force of the bishops' message of faith: the need for the audience to progressively grow in faith. The audience are expected to learn from St. Paul's experience so as to be able to confess similarly.

Text 2 is a paraphrased quotation from the holy Bible. It relates to the theme of love:

Text 2:...our love for God must express itself in our love for our neighbour, for we cannot claim to love God if we do not love our neighbour [7].

The quotation here derives from the first book of John to validate the claim that love of God has to be expressed through love of neighbour. The bishop finds the need to appeal to the authority of the holy Bible so as to convince the faithful to show love to their neighbours. Being very much aware that majority of the faithful claim to love God even while they hate their fellow human beings, the bishop decides to make it categorically clear to the faithful that their love for God can only be demonstrated through their love for their fellow human beings. He presents this as an obligation (through the use of the modal auxiliary must) which is binding on the faithful, and not as a matter of choice. To make himself authoritative, credible and convincing, he invokes the authority of the holy Bible, by echoing the message of love from the first book of John.

In text 3 , reference is made to the holy Bible through direct quotation.

Text 3: The Lord's invitation is very real: "Repent and believe the gospel" (Mark 1:15) [8].

In this text, which is a call to repentance, reference is made to the Gospel according to St. Mark, in form of direct quotation. The text is marked by the presence of quotation marks enclosing the exact words quoted, and then the biblical reference information enclosed in brackets. There is no better way of making this call to repentance appear genuine, believable and mandatory than quoting the exact words of the Lord himself in support of it. Direct quotation increases the level of acceptability of message as it makes it appear authentic and irrefutable. In fact, the bishop presents the call as coming directly from the Lord himself. This is highly persuasive, as the faithful is made to see response to the call as a matter of obedience, urgency and compulsion.

A similar effect is achieved through the use of direct quotation from the Bible in text 4 below:

Text 4: Hold on to the Catholic Church, "the Church of the living God, the pillar and support of the truth," (1 Tim. 3:15) and the Ark of Salvation[9].

Here, emphasis is on loyalty to the Roman Catholic Church. The audience are made to understand that the Roman Catholic Church is the only Church that guarantees the salvation of men, and so they need to remain steadfast to it. To make his message authoritative, credible, convincing, and persuasive, the bishop appeals to the authority of the Holy Bible, the first book of Timothy. The quotation shows that the message of the bishop is biblically based. This is an important persuasive factor as the Catholic faithful, now influenced by Pentecostal teachings, are beginning to doubt any message that is not supported by the Scriptures. The question is always: Where is it in the Bible?" The direct Biblical quotation thus serves to make the bishop's message convincing and acceptable. By making reference to the authority of the holy Bible, as seen in texts 1-4 above, the bishop makes himself credible and his messages of faith, love, repentance, and loyalty to the Catholic Church convincing and acceptable to the audience.

\section{2) Biblical allusions}

These entail indirect references to the holy Bible, taking 
for granted the audience's understanding, such that intelligibility is based on shared knowledge of the bishops and the audience. Allusions are made to the Bible for the purpose of making messages convincing and acceptable, as can be seen in text 5 :

Text 5: Let us make use of this period to listen to modern day Jonah and like the Ninevites give up our sinfulness and receive God. [10].

In text 5 above, which concerns the theme of repentance, an allusion is made to the Old Testament of the holy Bible in the book of Jonah. In the Biblical story of Jonah, God calls Jonah to go and preach to the people of Nineveh so that they would repent of their sins otherwise destruction would come upon them. Although Jonah tried unsuccessfully to dodge this assignment, he eventually got to Nineveh, preached to the people and they repented. Similarly the bishop calls on the faithful to use the period of Lent to listen to his call for repentance and give up their sins, just as the Ninevites listened to Jonah's call for repentance and gave up their sins. The bishop sees himself as the present day Jonah, and likens the audience to the Ninevites. This allusion is used to persuade the faithful to react positively to the bishop's message of repentance.

Text 6 is another instance of Biblical allusion in the bishops' pastoral letters.

Text 6: We cannot carry the new wine in an old wine skin! [8].

This text also relates to the theme of repentance. It is an allusion to the Holy Bible in the book of Luke (5:33-39), where Jesus gives a parable of the new wine and the old wineskins in relation to his teaching about fasting. He admonishes people not to pour new wine into old wineskins otherwise the skin will burst and the wine will waste. Rather, they should poor fresh wine into new wineskins to keep both in good condition. The bishop has made this allusion in order to advance the theme of repentance and persuade the faithful to make a positive response. He admonishes the faithful to have a complete renewal of life rather than claiming to be Christians while still clinging to their old sinful way of life.

Allusion is also made to the Holy Bible in texts 7 and 8 .

Text 7: We must be on guard against the weed that are being planted with demonic zeal to choke the good seeds. [9].

Text 8: Indeed, nothing can separate us from God's lovenot even our weakness and sinfulness [7].

In text 7 , which is in form of a warning and which relates to the theme of loyalty to the Catholic Church, the bishop alludes to the biblical parable of the wheat and the weeds as recorded in the book of Matthew (13: 24-30) [11]. Jesus has used this parable to tell the people what the kingdom of heaven would be like. In His explanation (Matthew, 13:3643), the good seed refers to the people who belong to the Kingdom; the weeds are the people who belong to the Evil One [11]. But to the bishop, who uses this allusion to create a dichotomy between teachers of Roman Catholic faith and those of non-Catholic faith, the weeds are the false teachings of preachers in non-Catholic Churches while the wheat, that is, the good seed, is the teaching of the Roman Catholic Church. The bishop warns the Catholic faithful to beware of non-Catholic teachers and their teachings. The allusion is aimed at persuading the faithful to remain loyal to the Roman Catholic faith.

Text 8 echoes St. Paul's statement that nothing can separate us from the love of God. It is an allusion to the book of Romans (8:38-39) in the Bible [11]. The bishop has used this allusion in order to assure the audience of God's unconditional love for them, despite their weakness and sinfulness. This is aimed at persuading them to return God's love through love for their fellow human beings.

Making reference to the Holy Bible in order to validate teachings is considered to be a strong persuasive device by the bishops. This is because the Bible is the holy book of Christianity and is regarded by Christians as the authoritative word of God. Any reference to it to buttress a point, either directly or indirectly renders the point indisputable. Who can dispute the Word of God?

\section{B. Reference to the Vatican Council}

Bishops' letters are also marked by references to the authority of the Vatican Council to authenticate messages. The Vatican Council is the highest ruling body in the Roman Catholic Church headed by the Pope. Whatever decision or regulation or teachings made by the Council on behalf of the Church is taken as absolute. The use of such a powerful authority to validate messages constitutes a strong persuasive force. Consider texts 9 and 10 below:

Text 9: According to the Fathers of the Second Vatican Council, "Whosoever, therefore, knowing that the Catholic Church was made necessary by God through Jesus Christ, would refuse to enter or remain in her could not be saved" [9], [12].

Text 10: The Council Fathers further made it clear that this love has to become a habit, a pattern of life, in fact, a culture when they insisted that this love is not something reserved for important matters, but must be exercised above all in the ordinary circumstances of daily life [13], [14].

In texts 9 and 10, references are made to two separate documents of the Vatican Council. The quotation in text 9 is a direct one, and is signaled by the adjunct according to the fathers of the Vatican Council. It is enclosed in quotation marks. The essence of this reference is to convince the faithful of why they should remain loyal to the Roman Catholic Church: it guarantees their salvation, so says the highest ruling body of the Church. This is convincing. By quoting the exact words of the Council Fathers, the bishop casts away from the minds of the faithful any doubt concerning the authority and the authenticity of this message of loyalty.

Text 10 contains a paraphrased quotation in form of a report from the Council Fathers' document. The aim is to convince the faithful to allow love to rule all aspects of their lives. What the Fathers say in this regard is important for the message to be driven home to the faithful. When you submit your final version, after your paper has been accepted, prepare it in two-column format, including figures and tables.

\section{Reference to the Catechism of the Roman Catholic Church}

The bishops in their Lenten pastorals have also made references to the Catechism of the Roman Catholic Church (CCC). This is another authoritative document in the Church, 
an official document containing the teachings of the Church. Appeal to this authority is an important persuasive factor in the bishops' letters, as seen in text 11 which relate to the theme of repentance:

Text 11: ...baptism is the principal place for the first and fundamental conversion. It is by baptism that one renounces evil and gains salvation, that is, the forgiveness of all sins and the gift of new life [15], [16].

Here, the audience are enjoined to activate the new life they received through baptism. Reference is made to the Catechism of the Roman Catholic Church (CCC) in order to convince them to do this. This document is a reference book on the Church teachings and doctrine and as such has the final say on such teachings and doctrine.

Another instance of an appeal to the authority of the Catechism of the Roman Catholic Church to validate messages and achieve persuasion is found in text 12 :

Text 12. According to the Catechism of the Catholic Church, "To live, grow and persevere in the faith until the end, we must nourish it with the word of God; we must beg the Lord to increase our faith; it must be 'working through charity' abounding in hope and rooted in the faith of the Church" [8], [15].

Direct quotation from the Catechism book is used to buttress the bishop's message to the audience, which is that they should to make efforts to grow in faith and exercise it in their daily living. The Church has already stipulated in the Catechism book the steps to follow in this regard. By quoting these steps exactly as they are outlined in the Church's book of Catechism, the bishop is likely to convince the audience of the authenticity of his message and persuade them to comply, especially as it is backed by such an authoritative document.

\section{Reference to the Canon Law}

The Canon Law is the system of laws and legal principles made and enforced by the hierarchical authorities of the Roman Catholic Church to regulate its external organization and government and to order and direct the activities of Catholics toward the mission of the Church. Like the other documents of the Church, the Canon Law is highly authoritative and revered in the Church. The content is indisputable. Citing it as an authority to validate messages is a strong persuasive device, as can be seen in texts 13 and 14:

Text 13: In accordance with Can. 1249, all Christ's faithful are obliged by divine law, each in his or her own way, to do penance at all times, but especially during Lent [16], [17].

Text 14: The most fundamental obligation is to maintain one's Catholic faith even at the risk of death. Besides...there are other obligations which the Catholic is bound to fulfill with the same zeal... [9], [17].

Here in text 13, which is a paraphrased quotation from the Canon Law relating to the subject of repentance, the bishop enjoins the audience to do penance at all times. This is expected to keep them always at peace with God. To convince them of the authenticity and importance of this message, the bishop appeals to the authority of the Canon Law. The audience have no choice than to abide by what the law of the Church stipulates. The authority of the Canon Law cannot be questioned. Reference to it is a strong persuasive device.

Likewise, in text 14, also a paraphrased quotation from the Canon Law, the authority of the document enhances acceptance of the bishop's message. The emphasis is on the theme of loyalty to the Roman Catholic Church. The audience are made to understand that, although there are other obligations a Catholic faithful is expected to fulfill, loyalty to the Church is the most important obligation which has to be fulfilled even at the cost of one's life. Reference to the Canon Law as the authority behind this message makes the message convincing.

\section{E. Reference to Pope}

In addition to making references to the holy Bible, the Vatican Council documents, the Catechism of the Catholic Church, and the Code of the Canon Law as authorities to validate messages, the bishops also appeal to the authority of the Pope to ensure acceptance of message. The pope as the Spiritual head of the Roman Catholic Church commands a high authority in the Church, and his documents are revered and held authoritative. This is because of the significance of the Petrine ministry in the Catholic Church. Catholics respect the teachings of the Pope because they believe that he is successor to Peter and is the supreme ruler and teacher of the Church [18]. The Supreme Pontiff, the Pope, is believed to be imbued with the fullness of the Christ-given authority. His stand on a particular issue is very important in the Catholic Church, and reference to his documents enables the bishops to convince the faithful to accept their messages. Consider text 15:

Text 15: It would be a perversion of love to reduce it to sex and its corollaries. Pope Benedict XVI speaks of this reductionist view of love as a "debasement of the human body" [7], [19].

In the above text, which relates to the theme of love, the bishop's message to the audience is that love should not be reduced to purely sexual relationship between man and woman. To facilitate acceptance of this message, he makes reference to the document of the Pope, as an authority. The reference is in form of direct quotation enclosed in quotation marks, with reference details in brackets. The directness of the quotation and the authority of its source make the bishop's message appear convincing. According to him, love means much more than just sexual attraction, sexual activity, and sexual satisfaction.

Similarly, in text 16, Papal document is cited to buttress teachings on the Christian faith.

Text 16:....Pope John Paul II in his address to some pilgrims from Reggio Emilia said "Christianity is a doctrine but it is, above all, a life which is understood to the extent to which it is practised" [20], [21].

Here reference is made to the document of the Pope to convince the faithful that beyond external verbal profession of faith or ritual religious acts, faith has to be expressed in good works. This message is given at the background of the bishop's observation that in spite of manifest religiosity in Nigeria, Christian impact is minimal in the Nigerian society. The Pope's view on the practicality of Christian faith is needed to convince the Catholic faithful to live in consonance with the faith they profess. As the spiritual leader of the Church, his position on religious issues is 
highly revered. The teachings of the bishop become more meaningful and acceptable to the faithful when the Pope's stand on the issues discussed is made clear to them.

\section{F. Reference to the Church Saints}

Reference to the authority of the Saints of the Church is another device employed by the bishops to add authority to their message so as to convince the faithful to accept it. In the Catholic Church the Saints are revered because they are seen as the early Christians who lived exemplary Christian lives and for that were canonized as Saints. They are considered to be the Fathers of the Church, and so their views concerning Catholic doctrine are held in high esteem. The doctrine of the Church is drawn from their teachings because they are seen to be part of the Church history, and as such are powerful testimony to the truth of the Catholic faith [22]. Text 17 is an instance of this.

Text 17: Naturally, God orders us to Himself. As St Augustine of Hippo writes "Our heart is restless until it rests in God" [10].

Here, in text 17 , reference is made to the authority of $\mathrm{St}$ Augustine of Hippo to drive home the message of repentance. The exact words of the Saint are enclosed in quotation marks and introduced by the adverbial clause as $\mathrm{St}$. Augustine of Hippo writes. This direct quotation increases the credibility of the bishop's message, making it authentic, authoritative and convincing.

Also, in text 18, reference is made to the authority of St. Ignatius of Antioch to buttress the message of loyalty to the Roman Catholic Church.

Text 18: According to St. Ignatius of Antioch, where there is Christ Jesus there is the Catholic Church [9]

The view of St. Ignatius is paraphrased with reference details in brackets. The paraphrased quotation is introduced by the adjunct according to St Ignatius of Antioch. It is used to back the bishop's teaching that the Roman Catholic Church is founded by Christ and as such is the only true Church of Christ that guarantees salvation of its members. Reference to the authority of the Saint is meant to convince the faithful to remain loyal to the Catholic Church.

\section{CONCLUSION}

The high preponderance of Testimonial references in the bishops ${ }^{\text {ee }}$ Lenten pastoral letters is attributable to the fact that the Catholic Church believes in hierarchy and obedience to authority. Disobedience to hierarchy and authority is considered a serious offence which attracts a penalty of excommunication. Reference to the authority of the Bible as the holy book of Christianity, the Vatican Council as the highest ruling body of the Church, the Catechism of the Roman Catholic Church, the Canon Law, the Pope as the spiritual head of the Church and the Vicar of Christ, and the Saints as Church Fathers and the pioneers of the Catholic faith is therefore a strong rhetorical device in the bishops' pastoral letters.
[2] K. Burke, The Rhetoric of Religion: Studies in Logology, Los Angeles CA: University of California Press, 1970.

[3] A. Baseer and S. D. Alvi, "An Analysis of barack obama's speech "The great need of the hour," Interdisciplinary Journal of Contemporary Research in Business, vol. 3, no. 9. pp. 617-635, 2012

[4] W. R. Robert. (2000). Aristotle, rhetoric, translated the internet classics archiv. [Online]. Available: http://classics.mit.edu//Aristotle/rhetoric.html

[5] K. Ikeida. (2009). Quotations pattern in Japanese. [Online]. Available: http://twpl.library.utoronto.ca/index.php/twpl/artiile/

[6] J. I. Okoye, Living the Faith, Enugu: SNAAP Press Ltd, 2006.

[7] J. I. Okoye, Living in the Amazing Love of God, Enugu: SNAAP Press Ltd., 2008.

[8] P. O. Okeke, We Walk by Faith, Onitsha: Goodmark Prints Production Inc. 2003.

[9] P. O. Okeke, From Faith to Faith, Onitsha: Goodmark Prints Production Inc., 2004.

[10] A. O. Gbuji, God Is Calling Us to Reconciliation, Enugu: SNAAP Press Ltd, 2001.

[11] Good News Bible, Catholic edition, New York: American Bible Society, 1976

[12] Vatican II. (1964). Dogmatic constitution on the church. [Online]. Available: www.vatican.va/archive/his-council/ii-vaticancouncil/documents/lumen-gentium.en. html

[13] Vatican II. (1965a).Gaudium et spes (Pastoral constitution of the church in the modern world), [Online]. Available: www. vatican.va/archive/his-council/ii-vatican-council/documents/gaudiumet-spes-en.html

[14] V. M. Okeke, The Measure of Love, Enugu: SNAAP Press Ltd, 2005.

[15] The Catechism of the Roman Catholic Church, 1427

[16] S. A. Okafor, Call to Conversion, Awka: Fides Communications, 2000.

[17] The Canon Law Society, Banglore: Theological Publication in India, 1997.

[18] C. Davis, The Church: A Living Heritage, New Jersey: Silver Burdett Company, 1982.

[19] Pope benedict XVI. Deus Caritas Est (God is love). [Online]. Available: www.vatican.va/ho-father/benedictxvi/encyclicals/documents/hf-ben-Xvi-enc-20051225-deus.

[20] P. J. Paul. Osservatore Roman. [Online]. Available: www.vatican.va/ho-father/johnpaul-ii/encyclicals/documents/hfjohnpaul-ii-enc.htm.

[21] V. M. Okeke, If Only You Have Faith, Enugu: SNAAP Press Ltd, 2006.

[22] J. R. Willis, The Teachings of the Church Fathers, San Francisco: Ignatius Press, 2002.

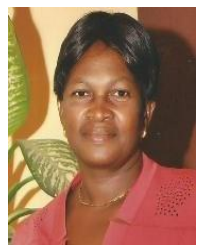

Virginia C. Okafor was born in Nnewi, Nnewi North Local Government Area of Anambra State, Nigeria in 1965. She had her first school leaving certificate and general certificate in education in Nnewi in 1979 and 1984 respectively. She obtained a bachelor of arts degree in English language at the University of Nigeria, Nsukka, in 1988; a master of arts degree in English language at the University of Ado-Ekiti, Nigeria, in 2002; and a doctorate degree in English language at the University of Ibadan, Nigeria, in 2014.

She is a chief lecturer at the Federal Polytechnic, Ado-Ekiti, Nigeria, where she has been teaching English language, English literature, and communication, since 1990 to date. She has numerous local and international publications among which are: Conflict Resolution through Effective Communication. Interdisciplinary Journal of Contemporary Research in Business (IJCRB)( Vol 5, no. 9. 321-334, 2014); Effectiveness of the Teaching and Learning of English Language and Communication in the Nigerian Polytechnics: A Study of the Federal Polytechnic, Ado-Ekiti. International Journal of Research in Education.(IJRE)( Vol.9, no.1. 23-32, 2012); Enhancing National Integration Through Literary Arts. Arts and Social Sciences Forum Journal (Vol.9, no.2. 30-38, 2002). Her research interests include discourse analysis and stylistics.

Dr. Okafor is a member of Modern Language Association of Nigeria (MLAN), a member of National Association for the Promotion of Studies in Arts and Social Sciences (NAPSASS), and a member of Nigerian English Studies Association (NESA).

\section{REFERENCES}

[1] L. Pernot, "The rhetoric of religion," Rhetorica, no. 3, pp. 235-254, 2006. 